\title{
Nanoantibodies: small molecules, big possibilities
}

\author{
Adriana Pedreáñez ${ }^{1 *}$, Jesús Mosquera-Sulbarán ${ }^{2}{\text {, Nelson } \text { Muñóz }^{3} \text {, Diego Tene }}^{4}$, Jorge Robalino ${ }^{5}$ \\ ${ }^{1}$ Cátedra de Inmunología, Escuela de Bioanálisis, Facultad de Medicina, Universidad del Zulia, Maracaibo, Venezuela \\ ${ }^{2}$ Instituto de Investigaciones Clínicas “Dr. Américo Negrette”, Facultad de Medicina, Universidad del Zulia, Maracaibo, Venezuela \\ ${ }^{3}$ Universidad Nacional del Chimborazo, Facultad de Ciencias de la Salud, Riobamba, Ecuador \\ ${ }^{4}$ Laboratorio Clínico del Hospital General IESS, Riobamba, Ecuador \\ ${ }^{5}$ Instituto INGINOST, Riobamba, Ecuador
}

\begin{abstract}
Camelids (camels, dromedaries, alpacas, llamas, and vicuñas) contain in their serum conventional heterodimeric antibodies as well as antibodies with no light chains (L) in their structure and composed of only heavy chains (H), called as HcAbs (heavy chain antibodies). Variable fragments derived from these antibodies, called as VHH or nanoantibodies (Nbs), have also been described. Since their discovery, Nbs have been widely used in the fields of research, diagnostics, and pharmacotherapy. Despite being approximately one-tenth the size of a conventional antibody, they retain similar specificity and affinity to conventional antibodies and are much easier to clone and manipulate. Their unique properties such as small size, high stability, strong antigen binding affinity, water solubility, and natural origin make them suitable for the development of biopharmaceuticals and nanoreagents. The present review aims to describe the main structural and biochemical characteristics of these antibodies and to provide an update on their applications in research, biotechnology, and medicine. For this purpose, an exhaustive search of the biomedical literature was performed in the following databases: Medline (PubMed), Google Scholar, and ScienceDirect. Meta-analyses, observational studies, review articles, and clinical guidelines were reviewed. Only original articles were considered to assess the quality of the evidence.
\end{abstract}

Key words: camelids, nanoantibodies, nanotechnology, nanoreagents, SARS-CoV-2, therapy

\section{Introduction}

In 1993, Hamers-Casterman and collaborators discovered by chance the presence of heavy chain antibodies of natural origin in the serum of a dromedary (Hamers-Casterman et al., 1993). Subsequently, several investigations established that all members of the camelid family (dromedaries, camels, llamas, vicuñas, and alpacas) produce antibodies composed of only heavy chains called HcAbs (heavy chain antibodies) in addition to conventional antibodies (Hamers-Casterman et al., 1993; Muyldermans, 2013). Later, it was found that some cartilaginous fish, including sharks and rays, also produce functional heavy chain immunoglobulins, called IgNAR (Shao et al., 2007; Zielonka et al., 2015).
In recent years, these antibodies have attracted considerable interest from pharmaceutical and biotechnology industries because of their peculiar properties, including small size (molecular mass of $95 \mathrm{kDa}$; their antigen-binding fragments have dimensions of $4 \mathrm{~nm} \times$ $2.5 \mathrm{~nm} \times 3 \mathrm{~nm}$ and are typically $12-14 \mathrm{kDa}$ in size), robust structure, high affinity and specificity, high accessibility, and high tissue penetration (Jovčevska et al., 2020). Therefore, the objective of the present review is to describe the main structural and biochemical characteristics of these antibodies and to provide an update on their applications in research, biotechnology, and medicine.

\footnotetext{
* Correspondence author: Cátedra de Inmunología, Escuela de Bioanálisis, Facultad de Medicina, Universidad del Zulia, Maracaibo, Venezuela; e-mail: apedreanez@gmail.com
} 


\section{Structural and biochemical characteristics of nanoantibodies}

Immunoglobulin $\mathrm{G}(\operatorname{IgG})$, one of the five isotypes present in humans, is the immunoglobulin found in the highest concentration in mammalian serum and the only one that crosses the placental barrier; it provides most of the antibody-based immunity and is present in four subclasses: IgG1, IgG2, IgG3, and IgG4. The subclass IgG1 is mainly used therapeutically as it provides a clear advantage in enhancing effector functions and has a longer serum half-life (approximately 21 days) (Elbakri et al., 2010; Stanfield and Wilson, 2014). The basic structure of conventional IgG consists of two identical heavy polypeptide chains ( $\mathrm{H}$ chains) and two identical light polypeptide chains (L chains) (Conroy et al., 2017). In other words, it is a heterotetrameric molecule. The $\mathrm{H}$ chain has four domains: one variable domain $(\mathrm{VH})$ and three constant domains $(\mathrm{CH} 1, \mathrm{CH} 2$, and $\mathrm{CH} 3)$, whereas the $\mathrm{L}$ chain consists of a variable domain (VL) and a constant domain $(\mathrm{CL})$, which are paired and interact noncovalently with the $\mathrm{VH}$ and $\mathrm{CH} 1$ domains, respectively (Cymer et al., 2018). These associations result in the formation of three independent regions, namely two $\mathrm{Fab}$ (fragment antigen binding) portions and a crystallizable fragment $(\mathrm{Fc})$, connected through a flexible linker in the hinge region. The Fab regions are identical in structure, usually flat or concave, with each region expressing a specific antigen binding site. The Fc region is important for other biological functions such as complement activation and opsonization (Czajkowsky et al., 2009; Diebolder et al., 2014). The N-terminal paired VH-VL domains constitute the paratopoietic or variable fragment (VF), within which there are hypervariable regions called complementarity determining regions (CDRs). There are three such regions in each of the VL and $\mathrm{VH}$ variable domains that determine the specificity, diversity, and affinity of the immunoglobulin; the remaining parts of the VH and VL domains have fragments called framework regions that support or afford structure to the molecular loops (Mix et al., 2006; Vidarsson et al., 2014; Chiu and Gilliland, 2016) (Fig. 1).

A notable exception to this conventional structure of mammalian IgG is found in camelid sera (Hamers-Casterman et al., 1993). These sera possess special IgG antibodies, known as heavy chain antibodies (HcAbs), so called because they have no L-chain and lack the first constant domain of the heavy chain $(\mathrm{CH} 1)$. In other words, their structure is homodimeric. In its N-terminal region, the $\mathrm{H}$-chain of the homodimeric protein contains a variable domain, referred to as $\mathrm{VHH}$, which serves to associate with its specific antigen, followed by two constant domains. The VHH in an HcAb is the structural and functional equivalent of the Fab fragment of conventional antibodies. Therefore, the antigen-binding site of HcAbs consists only of a single domain that is directly linked through a hinge region to the $\mathrm{Fc}$ domain (Khodabakhsh et al., 2018) (Fig. 1).

Similarly, the heavy chain antibodies (IgNAR) discovered in the shark bloodstream also possess a homodimeric structure of two heavy chain polypeptides, each comprising a single variable domain and five constant domains (homodimeric structure). Here, the variable domain was named VNAR (Shao et al., 2007) (Fig. 1).

These fully functional antibodies exhibit high specificity and high diversity and binding capacities similar to those of conventional antibodies, although they lack the light chain. Thus, an $\mathrm{HcAb}$ is only approximately half the size $(75-90 \mathrm{kDa})$ of a conventional antibody whose weight is approximately $150 \mathrm{kDa}$. Consequently, its smaller size and more compact architecture might be better suited for accessing hidden targets.

Variable portions VHH and VNAR derived from camelid and cartilaginous fish HcAbs, respectively, were termed nanobodies or nanoantibodies (Nbs) in 2003 (Jovčevska and Muyldermans, 2020); this is because of their small dimensional size of $2.5 \mathrm{~nm}$ diameter and $4 \mathrm{~nm}$ height, with an approximate weight of $12-15 \mathrm{kDa}$, in order to emphasize their smaller dimensional sizes compared to the larger molecular sizes of antigen-binding fragments (Fabs; 57 kDa) and single-chain variable fragments (scFvs; $\sim 27 \mathrm{kDa}$ ).

HcAbs and IgNARs are characterized by very high levels of somatic hypermutation, apparently in response to antigens, which implies a high rate of variability (Dooley et al., 2006; Khodabakhsh et al., 2018; Liu and Huang, 2018) (Fig. 2).

Nbs in general have unexpected physical properties: prolonged shelf life at $>4^{\circ} \mathrm{C}$ and at $\angle 20^{\circ} \mathrm{C}$, tolerance to temperature increase $\left(60-80^{\circ} \mathrm{C}\right.$, several weeks at $\left.37^{\circ} \mathrm{C}\right)$, and resistance to proteolytic degradation and exposure to nonphysiological $\mathrm{pH}$ ( $\mathrm{pH}$ range 3.0-9.0) and chemical denaturants (2-3 M guanidinium chloride, 6-8 M urea), which hardly damage their antigen binding capacity (Henry and MacKenzie, 2018; Ingram et al., 2018). 

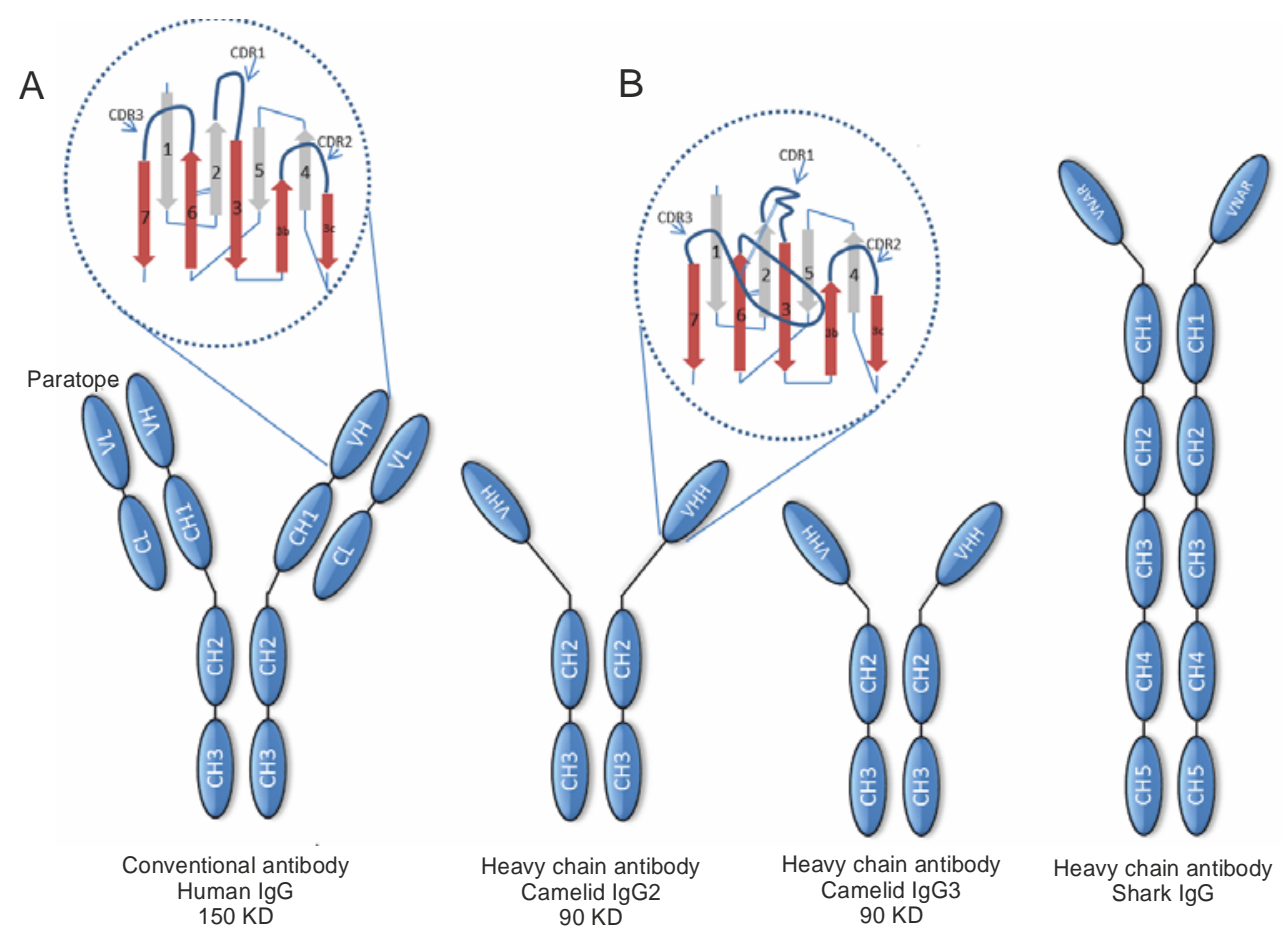

Fig. 1. Distinctive structural features of conventional antibodies (Abs) and heavy chain antibodies (HcAbs) of camelids and sharks. Conventional Abs are composed of heavy $(\mathrm{H})$ and light $(\mathrm{L})$ chains and are found in all vertebrates. HcAbs are found in camelids and sharks. The antigen-binding paratope of conventional Abs consists of the variable domains of the heavy and light chains (VH and VL), whereas the paratope of heavy-chain Acs consists only of the variable domain of the heavy chain, which is termed VHH in camelid HcAbs and VNAR in shark IgNARs. In HcAbs, the V domains are directly connected to the hinge region due to the lack of the $\mathrm{CH} 1$ domain. Camelid HcAbs have two variants, which are distinguished based on the lengths of their hinge region and are designated as long and short hinge isotypes (as shown in the figure). A and B: represent the hypervariable regions with their corresponding complementarity determining regions (CDRs) in conventional Acs and camelid HcAbs, respectively

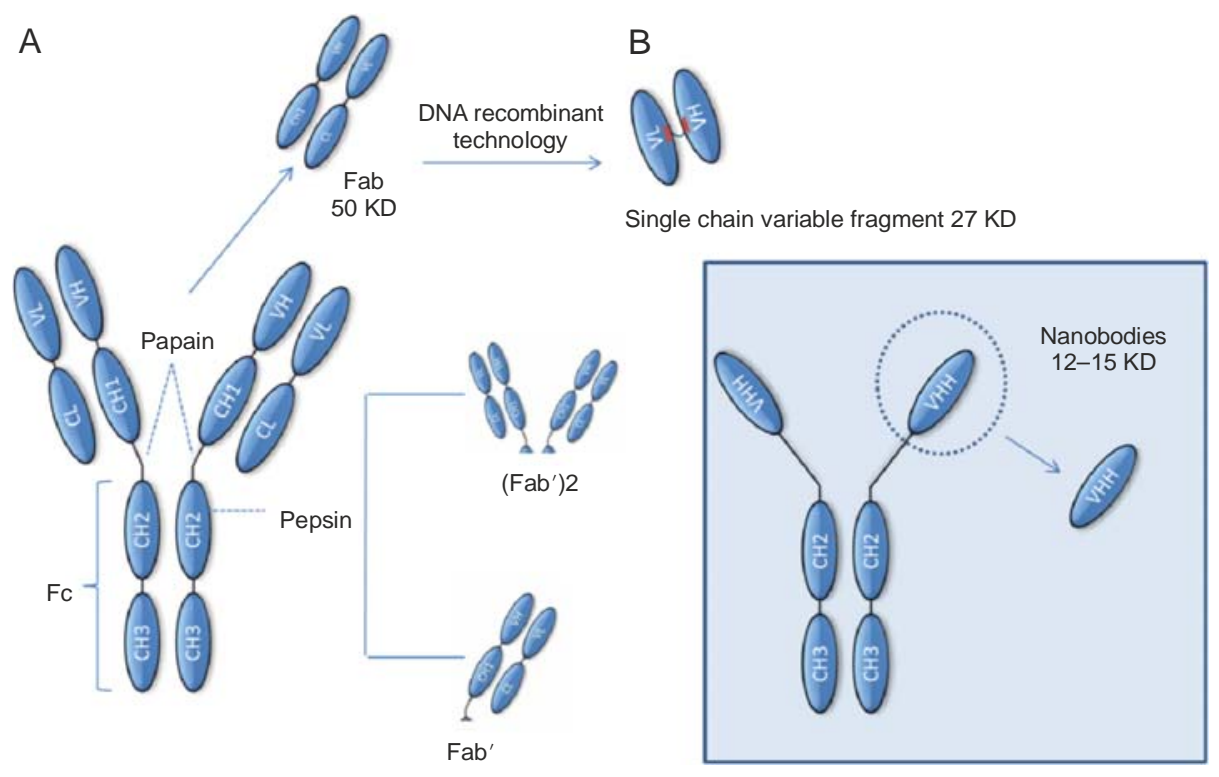

Fig. 2. Schematic representation of fragments obtained from immunoglobulins. These fragments can be generated by enzymatic proteolysis or through molecular biology techniques as in the case of Nbs. The smallest functional antigen-binding fragment that can be generated from conventional antibodies consists of a pair of VH-VL domains linked through an oligopeptide. These fragments are referred to as single-chain variable fragments ( $\mathrm{scFvs}$ ) (A). The smallest antigen-binding fragment obtained from $\mathrm{HcAbs}$ is the VHH, also known as a nanoantibody (B). Abbreviations: $\mathrm{CH}$ - constant heavy chain domain; Fab - antigen-binding fragment; $\mathrm{Fc}$ - crystallizable fragment; $\mathrm{scFv}$ - single-chain variable fragment 
As mentioned above, both conventional IgG antibodies and HcAbs circulate in camelid serum. The proportion of the latter is variable; in camels, it could range from 50 to $80 \%$, while in South American species (llamas, alpacas, vicuñas, and guanacos), it could range from 10 to $25 \%$ (Muyldermans S., 2013). In shark, the proportion of IgNAR is lower and is approximately $5 \%$ of the total immunoglobulins in the bloodstream (Zielonka et al., 2015; Henry and MacKenzie, 2018).

Although HcAbs have also been identified in cartilaginous fish (sharks and rays) (Zielonka et al., 2015), most research studies have been conducted on camelids because of their ease of handling and immunization.

\section{Production of Nbs}

The smaller size of HcAbs than that of conventional antibodies is relevant because for many applications, the size of a complete antibody is incompatible with some of the functions required for them, and hence, attempts are made to reduce the antibody molecules to the smallest unit that can recognize the antigen. This can be achieved by proteolytic digestion using papain and/or pepsin to obtain Fab fragments (Yamaguchi et al., 1995; Cheng., 2008). Although these fragments retain the antigen binding properties, considerable efforts are required to produce them properly (Leslie et al., 1971; Yamaguchi et al., 1995). Molecular biologists can further reduce these fragments to create the so-called single-chain variable fragments (scFvs) (Ahmad et al., 2012; Aubrey et al., 2019). The Fv fragment is the smallest unit of an immunoglobulin molecule with the ability to bind antigen. Therefore, $\mathrm{scFv}$ is formed by the variant regions of the heavy chain and light chain ( $\mathrm{Vh}$ and $\mathrm{Vl}$ ) linked by a flexible peptide linker that can be readily expressed in a functional form in Escherichia coli (Griffiths et al., 1998) (Fig. 2). To date, antibody fragments (scFvs) have been successfully isolated and displayed as fragments in various expression systems such as mammalian and yeast cells (Ho et al., 2006), plant cells (Galeffi et al., 2006), and insect cells (Choo et al., 2002). Numerous scFvs have been constructed against hormones (Kobayashi et al., 2008), different proteins (Dai et al., 2003; Guo et al., 2003), carbohydrates (Ravn et al., 2004; Sakai et al., 2007), receptors (Galeffi et al., 2006), tumor antigen (Noronha et al., 2002; Huehls et al., 2015; Yang et al., 2016), and viruses (Zhang and Dimitrov, 2007;
Ferrantelli et al., 2019). All these scFvs have good potential for use in many fields such as medical therapies and diagnostic applications. The problem that often arises with these fragments is that they have not passed through the secretory pathway of a eukaryotic cell and consequently tend to be prone to aggregation and may require considerable optimization before a stable product can be achieved (Ingram et al., 2018).

HcAbs produced by camelids have no such disadvantages because they can restrict the recognition modulus only to the variable region of the heavy chain, and unlike traditional antibodies, all the features of the structure required for antigen-specific recognition are located within the variable regions of the heavy chain (Henry and MacKenzie, 2018). As mentioned above, these VHH fragments are also commonly referred to as nanobodies or Nbs. Some of the properties that make these Nbs so attractive include 1) production in bacteria with high yields, 2) no requirement of glycosylation or disulfide linkages for many of these Nbs for stability, and 3) small size that allows applications for which even singlestranded $\mathrm{scFv}$ would have limitations (Harmsen and De Haard, 2007).

Cloning an $\mathrm{HcAb}$ from an immunized camelid is a simple process that requires an immunization schedule comprising 2 to 6 boosters over a period of 3 to 6 months. Most market applications of Nbs depend on reliable, cost-effective, high-volume production; therefore, cloning of the HHV repertoire from an immunized camelid into a phage presentation vector and the selection of antigen-specific clones by screening are usually the methods of choice (Saerens et al., 2004; Saerens et al., 2005; Reader et al., 2019).

Purified lymphocytes from peripheral blood, lymph node, or spleen of an immunized animal are typically obtained 4 to 14 days after the final booster dose and are used for the isolation of messenger ribonucleic acid (mRNA) and complementary deoxyribonucleic acid (DNA) synthesis. By using suitable primers to uniquely amplify the gene fragments encoding the VHHs, they are specifically amplified by polymerase chain reaction (PCR) (Schoonooghe et al., 2012). Subsequently, the purified PCR amplification products are cloned into a phagemid vector. These are then transfected into an $E$. coli strain after infection with a helper phage, and recombinant phage particle libraries are collected from bacterial culture supernatants; phages presenting the 


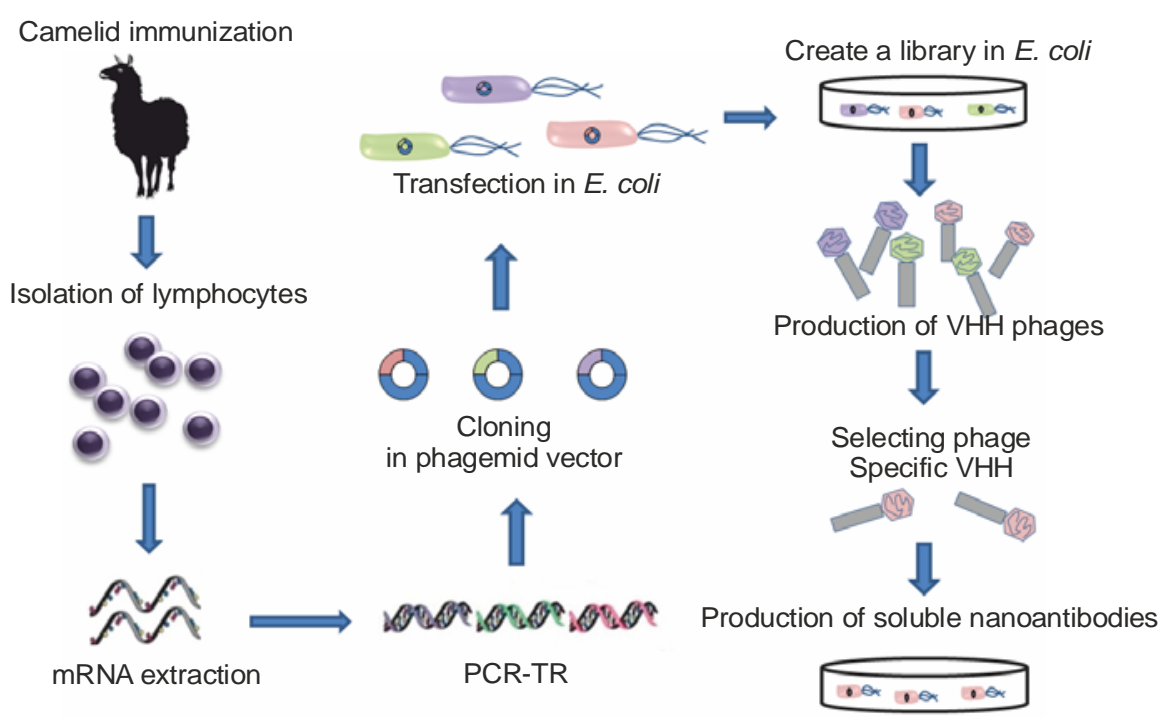

Fig. 3. Schematic representation of the Nbs production process. Following immunization of a camelid, the genes encoding HHV are generated from lymphocytes isolated from peripheral blood and cloned into a phagemid vector. Subsequently, antigenspecific clones are selected by screening

Nbs of interest are selected by screening on an immobilized antigen on a plate. The bound phages undergo one or more additional rounds of selection. Thus, although the process starts with animals immunized with different antigens, after several stages, Nbs of defined and unique specificity are obtained that can then be produced in bacteria with high yield (Schoonooghe et al., 2012; Behdani et al., 2012; Vincke and Muyldermans, 2012) (Fig. 3).

\section{Applicability of Nbs}

The unique physicochemical and pharmacokinetic properties of Nbs include nanoscale size, stable and soluble behavior in aqueous solution, high specific affinity, and a sustainable source. These qualities make them an ideal research tool for the development of sophisticated nanobiotechnologies (Muyldermans et al., 2009; Huang et al., 2010). These properties match the requirements of many biomedical applications and offer several advantages compared to the use of conventional antibodies for immunotherapy and diagnostics. The rapid and relatively easy induction of specific, high-affinity Nbs provides a broad repertoire of intracellular signaling molecules, protein-protein interactions, and biomarkers that can be used for treating cancer and inflammatory and autoimmune diseases (Schumacher et al., 2018; Messer and Butler, 2020; Cheloha et al., 2020). In this regard,
Nbs can be fused with fluorescent proteins to produce chromobodies that can be used in single-molecule localization with super-resolution imaging techniques (Rothbauer et al., 2006; Roovers et al., 2007; Platonova et al., 2015; Wang et al., 2016; Prole and Taylor, 2019; Salvador et al., 2019; Sograte-Idrissi et al., 2019).

Moreover, because Nbs can be designed to induce conformational changes or to discriminate between conformational variants, they may prove to be a beneficial research tool for monitoring protein expression, translocation, and subcellular localization (Kirchhofer et al., 2010; Farrants et al., 2020).

By using nanobodies fused to fluorescent proteins, some tracers have been developed for biological imaging in living cells. These "chromobodies" or "fluorobodies" are useful for tracing intracellular targets in various compartments in living cells (Rothbauer et al., 2006; Beghein and Gettemans, 2017; Traenkle and Rothbauer, 2017; Debie et al., 2019). Numerous chromobodies targeting proteins involved in cell cytoskeleton, nuclear lamina formation, and intermediate filaments such as actin have been described. For example, a lamin chromobody was identified and stably introduced into human cell lines (Schmidthals et al., 2010). Live cell imaging obtained from the signal generated by the chromobody allowed to reveal the typical nuclear rim structure and to monitor its disintegration during mitosis or apoptosis induction (Zolghadr et al., 2012). 
Chromobodies directed against other targets of the cell cytoskeleton, such as vimentin (VB6 chromobody) (Maier et al., 2015), a biomarker of epithelial-mesenchymal transition (EMT), which is a highly dynamic process involved in the initiation of metastasis and cancer progression (Battaglia et al., 2018), have also been generated.

Chromobodies directed against nuclear factors have also been a very important tool in live cell imaging. By visualizing the dynamic appearance of distinct nuclear foci, formed by proliferating cell nuclear antigen native (PCNA), a PCNA chromobody allowed for detailed analysis of cell cycle S-phase progression and quantitative live imaging of DNA replication in human cells (Burgess et al., 2012).

Nbs can be genetically customized to target enzymes, transmembrane proteins, or molecular interactions. Their ability to recognize poorly accessible antigenic sites makes them particularly interesting, and this property has been attributed to their smaller size and the ability of the extended CDR3 loop to rapidly penetrate such epitopes (Ariotti et al., 2018).

Nbs have been used to study protein-protein interactions in vivo (De Meyer et al., 2014). For example, by using Nbs, it was possible to visualize the p53-HDM2 interaction in living cells and to directly monitor the disruption of this interaction by Nutlin 3, a drug developed to boost p53 activity in cancer therapy (Herce et al., 2013). Inactivation of the p53 transcription factor by mutation or other mechanisms is a frequent event in tumorigenesis. One of the major endogenous negative regulators of p53 in humans is HDM2, an E3 ubiquitin ligase that binds to p53 and leads to its proteasomal degradation (Liu et al., 2016).

A variety of formats derived from Nbs include radionucleotide-labeled nanoantibody or fluorescent dye-labeled nanobodies, fluorescent protein fusion nanobodies, chromogenic enzyme-linked bivalent nanobodies, homoor heteromultimer motif-mediated self-assembly nanobodies, and nanobodies linked to coated nanoparticles. They have been successfully demonstrated as powerful nanobiotechnological toolkits for various biomedical applications, including drug delivery and therapy (De Marco, 2011) (Fig. 4).

In relation to their use for drug delivery, Nbs can chemically adhere to the surface of other drug delivery systems such as nanosized drug carriers or NPs, which

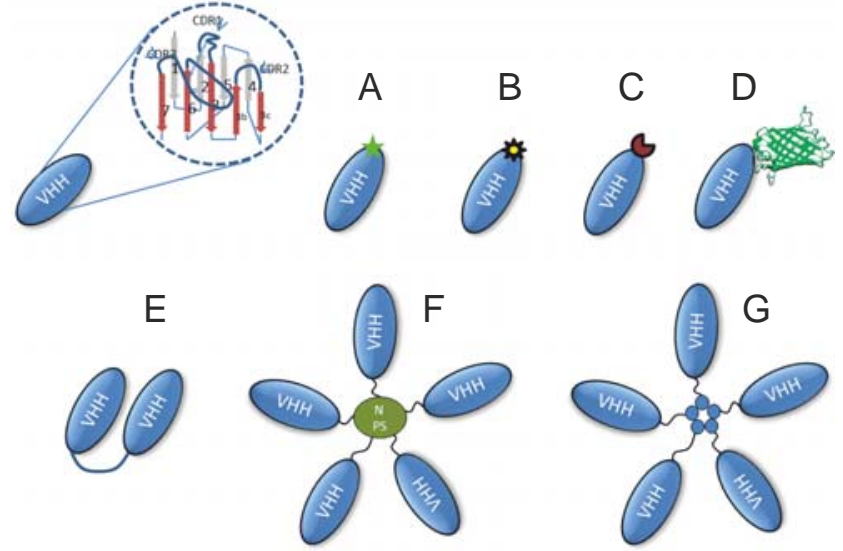

Fig. 4. Representative schematic of some of the different formats that can be produced using Nbs. Monovalent Nbs can be obtained directly from Escherichia coli transfected with selected phagemids as illustrated in Figure 3. The Nbs can be genetically customized to target enzymes, transmembrane proteins, or molecular interactions. Monovalent Nbs can be chemically conjugated with fluorochromes (A), radioisotopes (B), chromogenic enzymes $(\mathrm{C})$, and fluorescent proteins such as green fluorescent protein (D). In addition, bivalent structures of $\mathrm{Nbs}(\mathrm{E})$, nanoparticles coated with $\mathrm{Nbs}(\mathrm{F})$, and homo or heteromultimer of Nbs through nanoassembly domains $(\mathrm{G})$ can be created

can be encapsulated with specific drugs for active delivery to the site of interest. This mechanism protects the body against systemic toxicity and enables to solubilize hydrophobic drugs into hydrophilic structures such as liposomes or micelles (Muhammad et al., 2017). Significant progress has been made with an $\mathrm{Nb}$ coupled to a drug delivery system targeting the epidermal growth factor receptor (EGFR). The nanobody named EGa1 has been described as an EGFR antagonist, and the in vitro and in vivo effects of this system on EGFR internalization and downregulation have been investigated. In this regard, EGa1 liposomes (EGa1-L) induced EGFR clearance from more than $90 \%$ of the cell surface and significant inhibition of tumor cell proliferation in vitro. Moreover, in in vivo studies, downregulation of EGFR was observed in tumors of mice injected intravenously with EGa1-L (Oliveira et al., 2010).

Additionally, this same drug delivery system has been used in other studies in which micelle conjugates containing the chemotherapeutic drug doxorubicin (Talelli et al., 2013) or NANAPs filled with a multikinase inhibitor (Altintas et al., 2013) were used, which also induced downregulation of EGFR and subsequent inhibition of tumor cell proliferation. 
The use of Nbs has also been explored for diagnostic purposes (De Meyer et al., 2014), mainly in infectious diseases caused by highly pathogenic and potentially lethal agents. For example, an $\mathrm{Nb}$ against recombinant $\mathrm{N}$ protein ( $\mathrm{prN} \Delta 85$ ) from a Hantavirus strain was used in western blot assay and enzyme-linked immunosorbent assay (ELISA) and could rapidly detect native viral antigen in serum samples (Pereira et al., 2014).

Moreover, the small size, high affinity, and specificity for their target antigen make Nbs ideal probes for in vivo imaging (Schumacher et al., 2018). As an example of an application where this has been proven to be particularly useful is in the observation of vascular lesions in atherosclerosis. Because of the small size of lesions, it has been particularly difficult to obtain an in vivo lesion-tobackground ratio from images of atheromatous plaques in coronary arteries. High-contrast imaging at only $2-3 \mathrm{~h}$ after tracer administration has been documented using 99mTc-labeled nanobodies directed against vascular cell adhesion molecule-1 (VCAM-1) in hypercholesterolemic ApoE-deficient mice (Broisat et al., 2012).

Another interesting example of the use of Nbs in this area is the exploration of extracellular matrix (ECM) deposits, a hallmark of many diseases, including cancer and fibrosis. To exploit ECM as a therapeutic and imaging target, an alpaca-derived nanoantibody (NJB2) has been developed that recognizes the EIIIB domain (EDB) of fibronectin, a key ECM protein. Noninvasive in vivo immuno-PET/CT imaging successfully demonstrated that NJB2 detects primary tumors and metastatic sites with excellent specificity in multiple breast cancer models, including human and mouse triple-negative breast cancer and melanoma (Jailkhani et al., 2019).

The use of antibodies for therapeutic purposes is not new. The remarkable success of conventional neutralizing antibodies against tumor necrosis factor-alpha (TNF- $\alpha$ ) in the therapy of rheumatoid arthritis and other inflammatory diseases (Feldmann, 2002; Bek et al., 2017) has prompted the search for other antibody-based therapeutic tools. In this context, the use of Nbs has also been aimed at reducing the inflammatory effects that underlie many diseases. For example, the use of ALX-0061, an Nb with a high affinity and potency for the IL-6 receptor (IL-6R), which is a relevant application as interleukin-6 (IL-6) plays a key role in the pathogenesis of different diseases, including rheumatoid arthritis (Tanaka et al., 2014). The pharmacological properties of
ALX-0061 were examined in cynomolgus monkeys by using total plasma IL-6R as a pharmacodynamic marker. The therapeutic effect was evaluated in a human IL-6induced acute phase response model in the same species and in a collagen-induced arthritis (CIA) model in rhesus monkeys by using tocilizumab as a positive control. A 200 -fold increase in target affinity was obtained by affinity maturation of the parental domain. The high affinity for sIL-6R $(0.19 \mathrm{pM})$ resulted in complete and concentration-dependent neutralization of sIL-6R in vitro. In cynomolgus monkeys, ALX-0061 showed complete and dose-dependent inhibition of hIL-6-induced inflammatory parameters, including plasma levels of C-reactive protein (CRP), fibrinogen, and platelets (Van Roy et al., 2015). A summary of the main uses of Nbs in medicine and biotechnology is presented in Table 1.

Recently, an $\mathrm{Nb}$ was approved for therapeutic purposes (Duggan, 2018). Ablynx, a Sanofi company, developed the $\mathrm{Nb}$ caplacizumab (Cablivi ${ }^{\mathrm{TM}}$ ), an anti-von Willebrand factor (VWF), for the treatment of acquired thrombotic thrombocytopenic purpura (aTTP). It is an $\mathrm{Nb}$ that inhibits the interaction between platelets and very high-molecular-weight multimers of VWF, thereby preventing the formation and accumulation of microclots that cause thrombocytopenia, tissue ischemia, and organ dysfunction in aTTP. The treatment with caplacizumab has been associated with more rapid normalization of platelet counts and a lower incidence of aTTP-related death (Scully et al., 2019). A list of Nbs currently approved or in clinical trials for use in humans is shown in Table 2.

A promising aspect of the therapeutic use of Nbs is the fact that they can cross the blood-brain barrier (Muruganandam et al., 2002). In this regard, it was found that one of the Nbs isolated from llama that was immunized with cerebrovascular endothelial cells underwent transcytosis and was released on the basolateral side of the endothelial cells. In vivo studies demonstrated that the $\mathrm{Nb}$ was efficiently transported across the blood-brain barrier and could even be used to transport any cargo into the brain, including the entire M13 phage particle (Abulrob et al., 2005).

\section{Nbs in cancer therapy}

Monoclonal antibodies (mAbs) and antibody-derived biologics are essential tools for cancer research and 
Table 1. Summary of the main uses of nanoantibodies in medicine and biotechnology

\begin{tabular}{l|l}
\hline \multicolumn{1}{c|}{ Use } & \multicolumn{1}{c}{ Reference } \\
\hline Treatment of cancer & Strohl, 2018; Nikooharf et al., 2020; Kijanka et al., 2015 \\
\hline Direct antagonistic effects (bind to extracellular proteins) & Farrants et al., 2020; Kirchhofer et al., 2010 \\
\hline Nbs incorporated into drug delivery systems & Muhammad et al., 2017; Oliveira et al., 2010 \\
\hline Study protein-protein interactions in vivo & De Meyer et al., 2014; Herce et al., 2013 \\
\hline Nbs used for in vivo medical imaging & $\begin{array}{l}\text { Rothbauer et al., 2006; Roovers et al., 2007; } \\
\text { Platonova et al., 2015; Wang et al., 2016; Prole and Taylor, } \\
\text { 2019; Salvador et al., 2019; Sograte-Idrissi et al., 2019 }\end{array}$ \\
\hline $\begin{array}{l}\text { For tracing intracellular targets in various compartments } \\
\text { in living cells }\end{array}$ & $\begin{array}{l}\text { Rothbauer et al., 2006; Beghein and Gettemans, 2017; } \\
\text { Traenkle and Rothbauer, 2017; Debie et al., 2019 }\end{array}$ \\
\hline Nbs used as diagnostics & Pereira et al., 2014; Hoey et al., 2019 \\
\hline Nanobodies against inflammation and autoimmune diseases & Tanaka et al., 2014; Sadeghian-Rizi et al., 2019 \\
\hline Nbs against hematological disorders & Peyvandi et al., 2016; Scully et al., 2019 \\
\hline Nbs against viruses & $\begin{array}{l}\text { Vanlandschoot et al., 2011; Cardoso et al., 2014; } \\
\text { Ezzikouri et al., 2020; Hanke et al., 2020. }\end{array}$ \\
\hline Nbs for allergy treatment & Flicker et al., 2020 \\
\hline Nbs against neurodegenerative diseases & Messer and Butler., 2020; Gerdes et al., 2020 \\
\hline Nbs: nanobodies & \\
\hline
\end{tabular}

Table 2. Nanoantibodies currently approved or in clinical trials for use in humans

\begin{tabular}{|c|c|c|c|}
\hline Nanobody & Indication & Target & Status \\
\hline Caplacizumab & $\begin{array}{c}\text { acquired thrombotic } \\
\text { thrombocytopenic } \\
\text { purpura }\end{array}$ & $\begin{array}{l}\text { von Willebrand } \\
\text { factor }\end{array}$ & $\begin{array}{l}\text { approved } \\
\text { (Duggan et al., 2018; Scully et al., 2019) }\end{array}$ \\
\hline $\begin{array}{l}\text { Ozoralizumab } \\
\text { (ATN-103) }\end{array}$ & Rheumatoid arthritis & $\mathrm{TNF}$ & $\begin{array}{l}\text { clinical trial; phase II } \\
\text { (Kratz and Elsadek, 2012) }\end{array}$ \\
\hline $\begin{array}{l}\text { Vobarilizumab } \\
\text { ALX-0061 }\end{array}$ & $\begin{array}{c}\text { Rheumatoid arthritis } \\
\text { systemic lupus } \\
\text { erythematosus }\end{array}$ & Il-6 & $\begin{array}{l}\text { clinical trial; phase II } \\
\text { (Van Roy et al., 2015) }\end{array}$ \\
\hline ALX-0171 & $\begin{array}{l}\text { lower respiratory } \\
\text { tract infection }\end{array}$ & $\begin{array}{l}\text { respiratory syncytial } \\
\text { virus (RSV) }\end{array}$ & $\begin{array}{l}\text { clinical trial; phase II } \\
\text { (Detalle et al., 2015; Palomo et al., 2016) }\end{array}$ \\
\hline M1095 & psoriasis & $\begin{array}{l}\text { IL17A, IL17F } \\
\text { and IL17A/F }\end{array}$ & $\begin{array}{l}\text { clinical trial; phase II } \\
\text { (Svecova et al., 2019) }\end{array}$ \\
\hline $\begin{array}{l}\text { Bispecific nanobody-derived } \\
\text { CAR-T cells }\end{array}$ & $\begin{array}{l}\text { refractory/relapsed } \\
\text { B-cell lymphoma }\end{array}$ & CD19/CD20 & $\begin{array}{l}\text { clinical trial; phase I } \\
\text { (Albert et al., 2017; De Munter et al., 2018) }\end{array}$ \\
\hline $\begin{array}{l}\alpha \text {-ADAMTS-5 nanobody } \\
\text { M6495 }\end{array}$ & Osteoarthritis & ADAMTS-5 & $\begin{array}{l}\text { clinical trial; phase I } \\
\text { (Pereira et al., 2018; Siebuhr et al., 2018) }\end{array}$ \\
\hline VHH batch 203027 & diarrhea & rotavirus & $\begin{array}{l}\text { clinical trial; phase II } \\
\text { (Sarker et al., 2013) }\end{array}$ \\
\hline $\begin{array}{l}{\left[{ }^{131} \mathrm{I}\right]-\text { SGMIB anti-HER2 }} \\
\text { VHH1 }\end{array}$ & breast cancer & HER2 & $\begin{array}{l}\text { clinical trial; phase I } \\
\text { (D'Huyvetter et al., 2020) }\end{array}$ \\
\hline AD-114 & $\begin{array}{l}\text { idiopathic pulmonary } \\
\text { fibrosis }\end{array}$ & CXCR4 & $\begin{array}{l}\text { preclinical } \\
\text { (Griffiths et al., 2018) }\end{array}$ \\
\hline
\end{tabular}


therapy (Strohl, 2018). Antibodies can be used to inhibit tumor cell proliferation and as tools to define effector domains. Many mAbs directed against tumor cell surface proteins interfere with the function of such proteins, for example, by blocking signaling through a growth factor receptor or by inducing apoptosis. By opsonizing the tumor cells, antibodies can also mark them for attack by the complement system, NK cells, and macrophages (Arezumand et al., 2017). However, certain inherent structural properties limit the applicability of mAbs and antibody-derived biologics for tumor therapy. The large size of mAbs (four polypeptide chains, $150 \mathrm{kDa}$ ) can make access to tumor cells difficult. Nbs combine the beneficial properties of small molecules and mAbs, and therefore, they are attractive agents for the development of new therapeutic strategies. Their small size makes them useful for targeting antigens that reside in tissues that are weakly vascularized and poorly accessible. These molecules show better extravasation and tissue penetration than classical mAbs, which is obviously crucial for therapeutic applications (Nikooharf et al., 2020). Because of the high interstitial pressure, the penetration of a drug into the tumor is mediated by diffusion. As this process depends on molecular size, Nbs penetrate tumors much better than mAbs (Kijanka et al., 2015).

On the other hand, the growth of solid tumors depends on the formation of new blood vessels (angiogenesis). Nbs that interfere with this vascularization have been generated (Kazemi-Lomedasht et al., 2015; Arezumand et al., 2016). In this regard, a study by Oliveira et al (2012). compared the tumor distribution of $15 \mathrm{kDa}$ Nbs with a $150 \mathrm{kDa}$ mAb after conjugation with the IRDye $800 \mathrm{CW}$ (IR) fluorophore. The EGFR-specific 7D12-IR nanobody showed homogeneous distribution of the probe in human A431 tumor xenografts between $30 \mathrm{~min}$ and $2 \mathrm{~h}$ after injection, leading to relatively high tumor uptake, whereas the negative control R2-IR did not accumulate in tumors (Oliveira et al., 2012).

Thus far, potential targets for Nbs-based therapies are extracellular targets such as ligand receptors or differentially expressed transmembrane proteins in the cells of interest. To this end, Nbs have been developed against transmembrane growth factor receptors type 1 and 2 (TGRF1 and TGRF2, respectively), vascular endothelial growth factor receptor (VEGFR) (Behdani et al., 2012; Ma et al., 2016), tyrosine kinase receptor (c-Met)
(Slørdahl et al., 2013; Su et al., 2019), and chemokine receptor type 7 (CXCR7) (Maussang et al., 2013; Kijanka et al., 2015). These receptors are associated with different neoplasms. For example, VEGFR has been found to be expressed in different cancers, including brain, lung, breast, and colon cancer; c-Met was implicated in colon, breast, and ovarian cancer and hematological malignancies; and overexpression of CXCR7 was associated with breast and lung cancers (Hu et al., 2017; Moradi et al., 2020). Nbs have also been developed against extracellular targets such as hepatocyte growth factor (HGF) and chemokines (Vosjan et al., 2012).

\section{Use of Nbs in viral diseases and prospects in combat against SARS-CoV-2}

To combat viruses and prevent their spread, Nbs can interfere at different levels of the viral multiplication cycle, for example, by preventing virus binding to cells, virus entry into the cell, and its subsequent replication (Schotte et al., 2014). Nbs can also be used to extend our understanding of viral particle transmission. For example, intranasal administration of neutralizing $\mathrm{Nbs}$ can protect against different types of influenza viruses (e.g., H5N1 or H5N2) by preventing virus attachment to host cells and subsequent viral replication (Cardoso et al., 2014).

In this context, SARS-CoV-2 enters host cells through an interaction between the spike glycoprotein and the angiotensin-converting enzyme receptor 2 (ACE-2). Direct prevention of this interaction presents an attractive possibility for suppressing virus replication. In this regard, Hanke et al. (2020) and Ezzikouri et al. (2020) isolated and characterized an alpaca-derived single domain antibody VHH fragment, named Ty1, specifically directed against a globular domain (RBD) located on the distal surface of the SARS-CoV-2 spike protein, directly preventing its binding to ACE-2. Ty1 is a $12.8 \mathrm{kDa} \mathrm{Nb}$ that can be expressed in large quantities in bacteria, representing a great opportunity for its large-scale manufacture and making it an excellent candidate as an intervention against COVID-19.

Broad neutralizing antibodies such as 47D11, S309, and VHH-72 have recently been reported to target a conserved region in the receptor binding domain (RBD) of the S1 subunit of the spicule protein. Because of their small size and high stability, single-domain antibodies may have the ability to be delivered using an in- 
haler, thus making them potentially attractive therapies for respiratory infections (Ho, 2020).

\section{Limitations of Nbs and perspectives}

The biochemical and molecular characteristics of Nbs have been extensively described herein. These properties have been exploited in the fields of oncology, inflammation, infectious diseases, and molecular imaging and could potentially make a substantial difference in therapy and diagnostic testing. However, Nbs present some challenges that need to be overcome, and curiously, some of their characteristics may also constitute potential limitations. For example, Nbs possess a short half-life (Muyldermans et al., 2013); this may provide a safety advantage as the therapeutic agent could be rapidly eliminated from circulation in the case of a druginduced adverse event (Odunsi K, 2017). However, this feature can also be a limitation to diagnostic and therapeutic efficacy. To overcome this limitation, a panel of half-life extension technologies can be used, including fusion of Nbs to a human serum albumin-binding peptide or to linear and branched polyethylene glycol (PEG).

These techniques were applied to the Nb AD-114-a single domain antibody that specifically binds with high affinity to the $\mathrm{G}$ protein-coupled CXC chemokine receptor 4 (CXCR4) (Griffiths et al., 2016), a high-value therapeutic target implicated in cancer and fibrosis $(\mathrm{Xu}$ et al., 2007). To increase the therapeutic potential of AD-114, a systematic analysis of a panel of AD-114 variants after modification with a range of validated half-life extension technologies was recently performed, and it was successfully demonstrated that AD-114 is susceptible to and retains target binding activity after various $\mathrm{C}$-terminal modifications. Pharmacokinetic (PK) and halflife data acquired in mice, rats, and cynomolgus monkeys were reported and showed that conjugation to PEG and PA600 residues significantly increased the circulating half-life of this Nb (Griffiths et al., 2019).

Another limitation of the use of Nbs is related to their immunogenicity. Administration of antibodies for therapeutic purposes in humans can trigger the production of antidrug antibodies (ADA) (Salvador et al., 2019), which can have unintended consequences. Immunogenic responses to antibody therapies can affect both safety and pharmacokinetic properties that may modify the usefulness and efficacy of drugs (Harding et al., 2010). To minimize immunogenicity in humans, different strategies have been described to "humanize" Nbs. A nanobody differs from a human heavy chain variable domain in approximately 10 amino acids spread over its entire surface, of which, four amino acids are located in the framework-2 region (at positions 42,49 , 50 and 52) and the rest occupy a third longer antigenbinding loop (H3) that folds over this area (Hoey et al., 2019) (Fig. 1A and Fig. 1B). For therapeutic applications, the camelid-specific amino acid sequences in the camelid framework have to be mutated to their equivalent human heavy chain variable domain, i.e., humanized (Vincke et al., 2009; Harding et al., 2010; Kovalenko et al., 2013; Ubah et al., 2017). An alternative to humanizing single-domain antibodies of animal origin is to "camelize" human variable domains into single-domain antibodies by replacing amino acid residues in the $\mathrm{VH}$ domain framework (Davies and Riechmann, 1996; Riechmann, 1996; Tanha et al., 2001), and by substitutions in the CDRs (Martin et al., 1997; Bond et al., 2003), it is possible to obtain monomeric human $\mathrm{VH}$ domains.

The production of Nbs also faces challenges with respect to the accommodation of camels, llamas, alpacas, and other camelid species. At the end of a round of immunization, these animals are not slaughtered, and therefore, they must have permanent housing. In fact, although the expression and production of $\mathrm{Nbs}$ is inexpensive, the immunization of camelids is not, especially when compared with the immunization of smaller animals for the generation of Abs. This has given rise to the need to search for alternatives. For example, nonimmune or synthetic VHH libraries can be started (Olichon and de Marco, 2012; Yan et al., 2015), and antigenspecific high-affinity Nbs could be selected from semisynthetic libraries by using in vitro ribosome presentation technology, in which no cloning or transformation is required when constructing the mutant library (Yau et al., 2003).

The cumbersome immunization of camelids required to generate Nbs can be countered not only with the aforementioned nonimmune or synthetic libraries but also with immunization of smaller animals. Some research groups have generated transgenic mice that express correctly folded Nbs in B cells because they carry a mini-Ig construct encoding dromedary HHV or a hybrid llama-human antibody locus (Zou et al., 2005; Janssens et al., 2006; Brüggemann et al., 2006). In mature B cells 
of healthy mammals, except camelids, cellular release of single $\mathrm{H}$ chains without $\mathrm{L}$ chains is normally prevented in the ER. However, conventional B cell development is blocked at an immature B cell stage in $\mathrm{L}-/-(\kappa-/-\lambda-/-)$-deficient mice, and this leads to spontaneous production of HcAbs (Zou et al., 2007).

\section{Conclusions}

Since the discovery of naturally occurring HcAbs in camelid sera and the development of technologies to clone and identify their antigen-binding fragments, known as $\mathrm{Nbs}$, the number and range of potential applications of Nbs appear to have expanded. Backed by intrinsic beneficial biochemical and biophysical properties, Nbs are a robust targeting entity that can be easily assembled or incorporated into more complex constructs. Even in the absence of an intrinsic therapeutic effect, their conjugation with chemotherapeutic agents generates promising drug delivery compounds. Although small monomeric Nbs are often superior to classical antibodies for therapeutic applications, they still have their own drawbacks such as rapid renal clearance that prevents high loading in diseased tissue and induces renal toxicity. However, tools and strategies are available to design Nbs into nextgeneration constructs with higher efficacy and fewer side effects.

\section{References}

Abulrob A., Sprong H., Van Bergen en Henegouwen P., Stanimirovic D. (2005) The blood-brain barrier transmigrating single domain antibody: mechanisms of transport and antigenic epitopes in human brain endothelial cells. J. Neurochem. 95(4): 1201-1214.

Ahmad Z., Yeap S., Ali A., Ho W., Alitheen N., Hamid M. (2012) $s c F_{V}$ antibody: principles and clinical application. Clin. Develop. Immun. 2012: 980250.

Albert S., Arndt C., Feldmann A., Bergmann R., Bachmann D., Koristka S., Ludwig F., Ziller-Walter P., Kegler A., Gärtner S., et al. (2017) A novel nanobody-based target module for retargeting of $T$ lymphocytes to EGFR-expressing cancer cells via the modular UniCAR platform. Oncoimmunology 6(4): e1287246.

Altintas I., Heukers R., van der Meel R., Lacombe M., Amidi M., van Bergen En Henegouwen P.M., Hennink W.E., Schiffelers R., Kok R. (2013) Nanobody-albumin nanoparticles (NANAPS) for the delivery of a multikinase inhibitor 17864 to EGFR overexpressing tumor cells. J. Control. Rel. 165(2): 110-118.

Arezumand R., Alibakhshi A., Ranjbari J., Ramazani A., Muyldermans S. (2017) Nanobodies as novel agents for targe- ting angiogenesis in solid cancers. Front Immunol. 8: 1746.

Arezumand R., Mahdian R., Zeinali S., Hassanzadeh-Ghassabeh G., Mansouri K., Khanahmad H., Namvar-Asl N., Rahimi H., Behdani M., Cohan R.A. et al (2016) Identification and characterization of a novel nanobody against human placental growth factor to modulate angiogenesis. Mol. Immunol. 78: 183-192.

Ariotti N., Rae J., Giles N., Martel N., Sierecki E., Gambin Y., Hall T.E., Parton R.G. (2018) Ultrastructural localisation of protein interactions using conditionally stable nanobodies. PLoS Biol. 16(4): e2005473.

Aubrey N., Billiald P. (2019) Antibody fragments humanization: beginning with the end in mind. Meth. Mol. Biol. 1904: 231-252.

Battaglia R.A., Delic S., Herrmann H., Snider N.T. (2018) Vimentin on the move: new developments in cell migration. F1000Research, 7, F1000 Faculty Rev-1796.

Beghein E., Gettemans J. (2017) Nanobody technology: a versatile toolkit for microscopic imaging, protein-protein interaction analysis, and protein function exploration. Front Immunol. 8: 771.

Behdani M., Zeinali S., Khanahmad H., Karimipour M., Asadzadeh N., Azadmanesh K., Khabiri, A., Schoonooghe S., Habibi Anbouhi M., Hassanzadeh-Ghassabeh G. et al. (2012) Generation and characterization of a functional Nanobody against the vascular endothelial growth factor receptor-2; angiogenesis cell receptor. Mol. Immunol. 50(1-2): 35-41.

Bek S., Bojesen A.B., Nielsen J.V., Sode J., Bank S., Vogel U., Andersen V. (2017) Systematic review and meta-analysis: pharmacogenetics of anti-TNF treatment response in rheumatoid arthritis. Pharmacogenom. J. 17(5): 403-411.

Bond C., Marsters J., Sidhu S. (2003) Contributions of CDR3 to VH H domain stability and the design of monobody scaffolds for naive antibody libraries. J. Mol. Biol. 332(3): 643-655.

Broisat A., Hernot S., Toczek J., De Vos J., Riou L., Martin S., Ahmadi M., Thielens N., Wernery U., Caveliers V., et al. (2012) Nanobodies targeting mouse/human VCAM1 for the nuclear imaging of atherosclerotic lesions. Circ. Res. 110: 927-937.

Brüggemann M., Smith J. A., Osborn M.J., Corcos D., Zou X., Nguyen V., Muyldermans S. (2006) Heavy-chain-only antibody expression and B-cell development in the mouse. Crit. Rev. Immunol. 26(5): 377-390.

Burgess A., Lorca T., Castro A. (2012) Quantitative live imaging of endogenous DNA replication in mammalian cells. PloS one 7(9): e45726.

Cardoso F.M., Ibañez L.I., Van den Hoecke S., De Baets S., Smet A., Roose K., Schepens B., Descamps F.J., Fiers W., Muyldermans S. et al. (2014) Single-domain antibodies targeting neuraminidase protect against an H5N1 influenza virus challenge. J. Virol. 88(15): 8278-8296.

Cheloha R., Harmand T., Wijne C., Schwartz T., Ploegh H. (2020) Exploring cellular biochemistry with nanobodies. J. Biol. Chem. 295(45): 15307-15327. 
Cheng K. (2008) Radioiodinated anti-TAG-72 CC49 Fab'antibody fragment. [in:] Molecular imaging and contrast agent database (MICAD). National Center for Biotechnology Information (US).

Chiu M.L., Gilliland G.L. (2016) Engineering antibody therapeutics. Curr. Opin. Struct. Biol. 38: 163-173.

Choo A., Dunn R., Broady K., Raison R. (2002) Soluble expression of a functional recombinant cytolytic immunotoxin in insect cells. Protein Exp. Purif. 24(3): 338-347.

Conroy P.J., Law R.H., Caradoc-Davies T.T., Whisstock J.C. (2017) Antibodies: From novel repertoires to defining and refining the structure of biologically important targets. Methods 116: 12-22.

Cymer F., Beck H., Rohde A., Reusch D. (2018) Therapeutic monoclonal antibody $\mathrm{N}$-glycosylation - structure, function and therapeutic potential. J. Int. Assoc. Biol. Stand. 52: $1-11$.

Czajkowsky D., Shao Z. (2009) The human IgM pentamer is a mushroom-shaped molecule with a flexural bias. Proc. Nat. Acad. Sci. USA 106(35): 14960-14965.

Dai K., Zhu H., Ruan C. (2003) Generation and characterization of recombinant single chain $F_{V}$ antibody that recognizes platelet glycoprotein Ibalpha. Thrombosis Res. 109(2-3): 137-144.

Davies J., Riechmann L. (1996) Single antibody domains as small recognition units: design and in vitro antigen selection of camelized, human VH domains with improved protein stability. Protein Eng. 9(6): 531-537.

De Marco A. (2011) Biotechnological applications of recom binant single-domain antibody fragments. Microb. Cell Fact. 10: 44

De Meyer T., Muyldermans S., Depicker A. (2014) Nanobodybased products as research and diagnostic tools. Trends Biotechnol. 32(5): 263-270.

De Munter S., Ingels J., Goetgeluk G., Bonte S., Pille M., Weening K., Kerre T., Abken H., Vandekerckhove B. (2018) Nanobody based dual specific CARs. Int. J. Mol. Sci. 19(2): 403

Debie P., Devoogdt N., Hernot S. (2019) Targeted nanobodybased molecular tracers for nuclear imaging and imageguided surgery. Antibodies (Basel) 8(1): 12.

Detalle L., Stohr T., Palomo C., Piedra P.A., Gilbert B.E., Mas V., Millar A., PowerU. F., Stortelers C., Allosery K., et al. (2015) Generation and characterization of $A L X-0171$, a potent novel therapeutic nanobody for the treatment of respiratory syncytial virus infection. Antimicrob. Agents Chemother. 60(1): 6-13.

D’Huyvetter M., De Vos J., Caveliers V., Vaneycken I., Heemskerk J., Duhoux F.P., Fontaine C., Vanhoeij M., Windhorst A.D., van der Aa F., et al. (2020) Phase I trial of ${ }^{131}$ I-GMIB-Anti-HER2-VHH1, a new promising candidate for HER2-targeted radionuclide therapy in breast cancer patients. J. Nuclear Med. jnumed.120.255679. Advance online publication.

Diebolder C., Beurskens F., de Jong R., Koning R., Strumane K., Lindorfer M., Voorhorst M., Ugurlar D., Rosati S.,
Heck A., et al. (2014) Complement is activated by IgG hexamers assembled at the cell surface. Science 343(6176): $1260-1263$.

Dooley H., Flajnik M. (2006) Antibody repertoire development in cartilaginous fish. Develop. Comp. Immunol. 30(1-2): $43-56$.

Duggan S. (2018) Caplacizumab: first global approval [published correction] Drugs 78(15): 1639-1642.

Elbakri A., Nelson P.N., Abu Odeh R.O. (2010) The state of antibody herapy. Hum. Immunol. 71(12): 1243-1250.

Ezzikouri S., Nourlil J., Tsukiyama-Kohara K., Kohara M., El Ossmani H., Windisch M., Benjelloun S. (2020) Nanobodies: an unexplored opportunity to combat COVID-19. J. Biomol. Struct. Dyn. 2020: 1-3.

Farrants H., Tarnawski M., Müller T.G., Otsuka S., Hiblot J., Koch B., Kueblbeck M., Kräusslich H.G., Ellenberg J., Johnsson K. (2020) Chemogenetic control of nanobodies. Nat. Meth. 17(3): 279-282.

Feldmann M. (2002) Development of anti-TNF therapy for rheumatoid arthritis. Nat. Rev. Immunol. 2(5): 364-371.

Ferrantelli F., Arenaccio C., Manfredi F., Olivetta E., Chiozzini C., Leone P., Percario Z., Ascione A., Flego M., Di Bonito P., et al. (2019) The intracellular delivery of antiHPV16 E 7 scFVs through engineered extracellular vesicles inhibits the proliferation of HPV-infected cells. Int. J. Nanomed. 14: 8755-8768.

Flicker S., Zettl I., Tillib S.V. (2020) Nanobodies-useful tools for allergy treatment? Front. Immunol. 11: 576255.

Galeffi P., Lombardi A., Pietraforte I., Novelli F., Di Donato M., Sperandei M., Tornambé A., Fraioli R., Martayan A., Natali P., et al. (2006) Functional expression of a singlechain antibody to ErbB-2 in plants and cell-free systems. J. Transl. Med. 4: 39.

Gerdes C., Waal N., Offner T., Fornasiero E., Wender N., Verbarg H., Manzini I., Trenkwalder C., Mollenhauer B., Strohäker T. et al. (2020) A nanobody-based fluorescent reporter reveals human $\alpha$-synuclein in the cell cytosol. Nature Comm. 11(1): 2729.

Griffiths K., Binder U., McDowell W., Tommasi R., Frigerio M., Darby W., Hosking C., Renaud L., Machacek M., Lloyd P., et al. (2019) Half-life extension and non-human primate pharmacokinetic safety studies of i-body AD-114 targeting human CXCR4. MAbs, 11(7): 1331-1340.

Griffiths K., Habiel D. M., Jaffar J., Binder U., Darby W.G., Hosking C.G., Skerra A., Westall G.P., Hogaboam C.M., Foley M. (2018) Anti-fibrotic effects of CXCR4-targeting ibody $A D-114$ in preclinical models of pulmonary fibrosis. Sci. Rep. 8(1): 3212.

Griffiths K., Dolezal O., Cao B., Nilsson S.K., See H., Pfleger K., Roche M., Gorry P., Pow A., Viduka K. et al. (2016) ibodies, human single domain antibodies that antagonize chemokine receptor CXCR4. J. Biol. Chem. 291(24): 12641-12657.

Griffiths A.D., Duncan A.R. (1998) Strategies for selection of antibodies by phage display. Curr. Opin. Biotech. 9(1): 102-108. 
Guo J.Q., You S., Li L., Zhang Y., Huang J., Zhang C. (2003) Construction and high-level expression of a single-chain $F_{V}$ antibody fragment specific for acidic isoferritin in Escherichia coli. J. Biotech. 102(2): 177-189.

Hamers-Casterman C., Atarhouch T., Muyldermans S., Robinson G., Hamers C., Songa E.B., Bendahman N., Hamers R. (1993) Naturally occurring antibodies devoid of light chains. Nature 363(6428): 446-448.

Hanke L., Vidakovics Perez L., Sheward D.J., Das H., Schulte T., Moliner-Morro A., Corcoran M., Achour A., Karlsson Hedestam G.B., Hällberg B.M., et al. (2020) An alpaca nanobody neutralizes SARS-CoV-2 by blocking receptor interaction. Nat. Commun. 11(1): 4420.

Harding F., Stickler M., Razo J., DuBridge R. (2010) The immunogenicity of humanized and fully human antibodies. residual immunogenicity resides in the CDR regions. MAbs, 2(3): 256-265

Harmsen M.M., De Haard H.J. (2007) Properties, production, and applications of camelid single-domain antibody fragments. Appl. Microbiol. Biotechnol. 77(1): 13-22.

Henry K.A., MacKenzie C.R. (2018) Antigen recognition by single-domain antibodies: structural latitudes and constraints. MAbs. 10(6): 815-826.

Herce H.D., Deng W., Helma J., Leonhardt H., Cardoso M.C. (2013) Visualization and targeted disruption of protein interactions in living cells. Nature Commun. 4: 2660.

Ho M. (2020) Perspectives on the development of neutralizing antibodies against SARS-CoV-2. Antib. Ther. 3(2): 109-114.

Ho M., Nagata S., Pastan I. (2006) Isolation of anti-CD22 $F_{V}$ with high affinity by $F_{V}$ display on human cells. Proc. Natl. Acad. Sci. USA 103(25): 9637-9642.

Hoey R., Eom H., Horn J.R. (2019) Structure and development of single domain antibodies as modules for therapeutics and diagnostics. Exp. Biol. Med. 244(17): 1568-1576.

Hu Y., Liu C., Muyldermans S. (2017) Nanobody-based delivery systems for diagnosis and targeted tumor therapy. Front. Immunol. 8: 1442.

Huang L., Muyldermans S., Saerens D. (2010) Nanobodies $\AA$ : proficient tools in diagnostics. Expert Rev. Mol. Diagn. 10(6): 777-785.

Huehls A., Coupet TA., Sentman CL. (2015) Bispecific T-cell engagers for cancer immunotherapy. Immunol. Cell Biol. 93(3): 290-296.

Ingram J.R., Schmidt F.I., Ploegh H.L. (2018) Exploiting nanobodies' singular traits. Annu. Rev. Immunol. 36: 695-715.

Jailkhani N., Ingram J., Rashidian M., Rickelt S., Tian, C., Mak H., Jiang Z., Ploegh H., Hynes R. (2019) Noninvasive imaging of tumor progression, metastasis, and fibrosis using a nanobody targeting the extracellular matrix. Proc. Natl. Acad. Sci. USA 116(28): 14181-14190.

Janssens R., Dekker S., Hendriks R., Panayotou G., van Remoortere A., San J., Grosveld F., Drabek D. (2006) Generation of heavy-chain-only antibodies in mice. Proc. Natl. Acad. Sci. USA 103: 15130-15135

Jovčevska I., Muyldermans S. (2020) The therapeutic potential of nanobodies. BioDrugs. 34(1): 11-26.
Kazemi-Lomedasht F., Behdani M., Bagheri K.P., HabibiAnbouhi M., Abolhassani M., Arezumand R., Shahbazzadeh D., Mirzahoseini H. (2015) Inhibition of angiogenesis in human endothelial cell using VEGF specific nanobody. Mol. Immunol. 65(1): 58-67.

Khodabakhsh F., Behdani M., Rami A., Kazemi-Lomedasht F. (2018) Single-domain antibodies or nanobodies: a class of next-generation antibodies. Int. Rev. Immunol. 37(6): 316-322.

Kijanka M., Dorresteijn B., Oliveira S., van Bergen., Henegouwen P.M. (2015) Nanobody-based cancer therapy of solid tumors. Nanomedicine 10(1): 161-174.

Kirchhofer A., Helma J., Schmidthals K., Frauer C., Cui S., Karcher A., Pellis M., Muyldermans S., Casas-Delucchi C.S., Cardoso M.C., et al. (2010) Modulation of protein properties in living cells using nanobodies. Nat. Struct. Mol. Biol. 17(1): 133-138.

Kobayashi N., Kato Y., Oyama H., Taga S., Niwa T., Sun P., Ohtoyo M., Goto J. (2008) Anti-estradiol-17beta singlechain $F_{V}$ fragments: generation, characterization, gene randomization, and optimized phage display. Steroids 73(14): 1485-1499.

Kovalenko O., Olland A., Piché-Nicholas N., Godbole A., King D., Svenson K., Calabro V., Müller M.R., Barelle C., Somers W. et al. (2013) Atypical antigen recognition mode of a shark immunoglobulin new antigen receptor (IgNAR) variable domain characterized by humanization and structural analysis. J. Biol. Chem. 288(24): 17408-17419.

Kratz F., Elsadek B. (2012) Clinical impact of serum proteins on drug delivery. J. Contr. Rel. 161(2): 429-445.

Leslie R., Melamed M., Cohen S. (1971) The products from papain and pepsin hydrolyses of guinea-pig immunoglobulins gamma $1 G$ and gamma 2 G. Bioch. J. 121(5): 829-837.

Liu L.J., He B., Miles J., Wang W., Mao Z., Che W., Lu J., Chen X., Wilson A., Ma D. et al. (2016) Inhibition of the p53/hDM2 protein-protein interaction by cyclometallated iridium(III) compounds. Oncotarget 7(12): 13965-13975.

Liu Y., Huang H. (2018) Expression of single-domain antibody in different systems. Appl. Microbiol. Biotechnol. 102(2): 539-551.

Maier J., Traenkle B., Rothbauer U. (2015) Real-time analysis of epithelial-mesenchymal transition using fluorescent single-domain antibodies. Sci. Rep. 5: 13402.

Martin F., Volpari C., Steinkuhler C., Dimasi N., Brunetti M., Biasiol G., Altamura S., Cortese R., De Francesco R., Sollazzo M. (1997) Affinity selection of a camelized $V(H)$ domain antibody inhibitor of hepatitis $C$ virus NS3 protease. Protein Eng. 10(5): 607-614.

Maussang D., Mujić-Delić A., Descamps F., Stortelers C., Vanlandschoot P., Stigter-van Walsum M., Vischer H.F., van Roy M., Vosjan M., Gonzalez-Pajuelo M., et al. (2013) Llama-derived single variable domains (nanobodies) directed against chemokine receptor $C X C R 7$ reduce head and neck cancer cell growth in vivo. J. Biol. Chem. 288(41): 29562-29572. 
Messer A., Butler D. (2020) Optimizing intracellular antibodies (intrabodies/nanobodies) to treat neurodegenerative disorders. Neurobiol. Dis. 134: 104619.

Mix E., Goertsches R., Zett U. (2006) Immunoglobulins-basic considerations. J. Neurol. 253(suppl. 5): V9-V17.

Moradi A., Pourseif M.M., Jafari B., Parvizpour S., Omidi Y. (2020) Nanobody-based therapeutics against colorectal cancer: precision therapies based on the personal mutanome profile and tumor neoantigens. Pharmacol. Res. 156: 104790.

Muhammad F., Nguyen TDT., Raza A., Akhtar B., Aryal S. (2017) A review on nanoparticle-based technologies for biodetoxification. Drug Chem. Toxicol. 40(4): 489-497.

Muruganandam A., Tanha J., Narang S., Stanimirovic D. (2002) Selection of phage-displayed llama single-domain antibodies that transmigrate across human blood-brain barrier endothelium. FASEB J. 16(2): 240-242.

Muyldermans S. (2013) Nanobodies: natural single-domain antibodies. Annu. Rev. Biochem. 82: 775-797.

Muyldermans S., Baral T.N., Retamozzo V.C., De Baetselier P., De Genst E., Kinne J., Leonhardt H., Magez S., Nguyen V.K., Revets H., et al. (2009) Camelid immunoglobulins and nanobody technology. Vet. Immunol. Immunopathol. 128(1-3): 178-183.

Nikooharf A., Arezumand R., Mansouri K., Khoshi AH., Namdar Ahmadabad H. (2020) Development of a recombinant monospecific anti-PLGF bivalent nanobody and evaluation of it in angiogenesis modulation. Mol. Biotech. 62(11-12): 580-588.

Noronha E., Wang X., Ferrone S. (2002) Isolation of human tumor-associated cell surface antigen-binding $S c F_{V S}$. Meth. Mol. Biol. 178: 227-233.

Odunsi K. (2017) Immunotherapy in ovarian cancer. Ann. Oncol. 7(28): viii1-viii7.

Olichon A., de Marco A. (2012) Preparation of a naïve library of camelid single domain antibodies. Meth. Mol. Biol. 911: 65-78.

Oliveira S., Schiffelers R. M., van der Veeken J., van der Meel R., Vongpromek R., van Bergen En Henegouwen P. M., Storm G., Roovers R. (2010) Downregulation of EGFR by a novel multivalent nanobody-liposome platform. J. Controll. Rel. 145(2): 165-175.

Oliveira S., van Dongen G., Stigter-van Walsum M., Roovers R., Stam J. C., Mali W., van Diest P., van Bergen en Henegouwen P. (2012) Rapid visualization of human tumor xenografts through optical imaging with a near-infrared fluorescent anti-epidermal growth factor receptor nanobody. Mol. Imag. 11(1): 33-46.

Palomo C., Mas V., Detalle L., Depla E., Cano O., Vázquez M., Stortelers C., Melero J. A. (2016) Trivalency of a nanobody specific for the human respiratory syncytial virus fusion glycoprotein drastically enhances virus neutralization and impacts escape mutant selection. Antimicrob. Agents Chemother. 60(11): 6498-6509.

Pereira J., Ottevaere I., Serruys B., Dejonckheere E., BayJensen A.C., Siebuhr A.S., El Bawab S., Ladel C., Linde- mann S. (2018) Pharmacokinetic and pharmacodynamic modelling of the novel anti-ADAMTS-5 nanobody M6495 using the neo-epitope ARGS as a biomarker. Osteoarthr. Cartil. 26: S176.

Pereira S., Moreira-Dill L., Morais M., Prado N., Barros M., Koishi A., Mazarrotto G., Gonçalves G., Zuliani J., Calderon L., et al. (2014) Novel camelid antibody fragments targeting recombinant nucleoprotein of Araucaria hantavirus: a prototype for an early diagnosis of Hantavirus Pulmonary Syndrome. PloS one 9(9): e108067.

Peyvandi F., Scully M., Kremer Hovinga J.A., Cataland S., Knöbl P., Wu H., Artoni A., Westwood J.P., Mansouri Taleghani M., Jilma B., et al. (2016) Caplacizumab for acquired thrombotic Thrombocytopenic purpura. New Engl. J. Med. 374(6): 511-522.

Platonova E., Winterflood C. M., Junemann A., Albrecht D., Faix J., Ewers H. (2015) Single-molecule microscopy of molecules tagged with GFP or RFP derivatives in mammalian cells using nanobody binders. Methods 88: 89-97.

Prole D.L., Taylor C.W. (2019) A genetically encoded toolkit of functionalized nanobodies against fluorescent proteins for visualizing and manipulating intracellular signalling. BMC Biol. 17(1): 41.

Ravn P., Danielczyk A., Jensen K.B., Kristensen P., Christensen P. A., Larsen M., Karsten U., Goletz S. (2004) Multivalent $s c F_{V}$ display of phagemid repertoires for the selection of carbohydrate-specific antibodies and its application to the Thomsen-Friedenreich antigen. J. Mol. Biol. 343(4): 985-996.

Reader R.H., Workman R.G., Maddison B.C., Gough K.C. (2019) Advances in the production and batch reformatting of phage antibody libraries. Mol. Biotechnol. 61(11): 801-815.

Riechmann L. (1996) Rearrangement of the former VL interface in the solution structure of a camelised, single antibody VH domain. J. Mol. Biol. 259(5): 957-969.

Roovers R., van Dongen G., van Bergen en Henegouwen P. (2007) Nanobodies in therapeutic applications. Curr. Opin. Mol. Ther. 9(4): 327-335.

Rothbauer U., Zolghadr K., Tillib S., Nowak D., Schermelleh L., Gahl A., Backmann N., Conrath K., Muyldermans S., Cardoso M.C., et al. (2006) Targeting and tracing antigens in live cells with fluorescent nanobodies. Nature Meth. 3(11): 887-889.

Sadeghian-Rizi T., Behdani M., Khanahmad H., Sadeghi H. M., Jahanian-Najafabadi A. (2019) Generation and characterization of a functional nanobody against inflammatory chemokine CXCL10, as a novel strategy for the treatment of multiple sclerosis. CNS Neurol. Dis. Drug Targets 18(2): 141-148.

Saerens D., Frederix F., Reekmans G., Conrath K., Jans K., Brys L., Huang L., Bosmans E., Maes G., Borghs G., et al. (2005) Engineering camel single-domain antibodies and immobilization chemistry for human prostate-specific antigen sensing. Anal. Chem. 77(23): 7547-7555.

Saerens D., Kinne J., Bosmans E., Wernery U., Muyldermans S., Conrath K. (2004) Single domain antibodies derived 
from dromedary lymph node and peripheral blood lymphocytes sensing conformational variants of prostate-specific antigen. J. Biol. Chem. 279(50): 51965-51972.

Sakai K., Shimizu Y., Chiba T., Matsumoto-Takasaki A., Kusada Y., Zhang W., Nakata M., Kojima N., Toma K., Takayanagi A., et al. (2007) Isolation and characterization of phage-displayed single chain antibodies recognizing nonreducing terminal mannose residues. 1. A new strategy for generation of anti-carbohydrate antibodies. Biochemistry 46(1): 253-262.

Salvador J., Vilaplana L., Marco M. (2019) Nanobody: outstanding features for diagnostic and therapeutic applications. Anal. Bioanal. Chem. 411(9): 1703-1713.

Sarker S., Jäkel M., Sultana S., Alam N., Bardhan P., Chisti M., Salam M., Theis W., Hammarström L., Frenken L. (2013) Anti-rotavirus protein reduces stool output in infants with diarrhea: a randomized placebo-controlled trial. Gastroenterology 145(4): 740-748.

Schmidthals K., Helma J., Zolghadr K., Rothbauer U., Leonhardt H. (2010) Novel antibody derivatives for proteome and high-content analysis. Anal. Bioanal. Chem. 397(8): 3203-3208.

Schoonooghe S., Laoui D., Van Ginderachter J.A., Devoogdt N., Lahoutte T., De Baetselier P., Raes G. (2012) Novel applications of nanobodies for in vivo bio-imaging of inflamed tissues in inflammatory diseases and cancer. Immunobiology 217(12): 1266-1272.

Schotte L., Strauss M., Thys B., Halewyck H., Filman D.J., Bostina M., Hogle J.M., Rombaut, B. (2014) Mechanism of action and capsid-stabilizing properties of VHHs with an in vitro antipolioviral activity. J. Virol. 88(8): 4403-4413.

Schumacher D., Helma J., Schneider A.F.L., Leonhardt H., Hackenberger C.P.R. (2018) Nanobodies: chemical functionalization strategies and intracellular applications. Angew. Chem. Int. Ed. Engl. 57(9): 2314-2333.

Scully M., Cataland S.R., Peyvandi F., Coppo P., Knöbl P., Kremer Hovinga J.A., Metjian A., de la Rubia J., Pavenski K., Callewaert F., et al. (2019) Caplacizumab treatment for acquired thrombotic Thrombocytopenic purpura. N. Engl. J. Med. 380(4): 335-346.

Shao C.Y., Secombes C.J., Porter A.J. (2007) Rapid isolation of IgNAR variable single-domain antibody fragments from a shark synthetic library. Mol. Immunol. 44(4): 656-665.

Siebuhr A., Bay-Jensen AC., Thudium CT., Karsdal MA., Serruys B., Werkmann D. (2018) The anti-ADAMTS-5 nanobody ${ }^{(} \mathrm{M} 6495$, protects against cartilage breakdown in cartilage and synovial joint tissue explant models. Osteoarthr. Cartil. 26: S187.

Slørdahl T., Denayer T., Moen S., Standal T., Børset M., Ververken C., Rø, T. (2013) Anti-c-MET nanobody - a new potential drug in multiple myeloma treatment. Eur. J. Haematol. 91(5): 399-410.

Sograte-Idrissi S., Oleksiievets N., Isbaner S., Eggert-Martinez M., Enderlein J., Tsukanov R., Opazo F. (2019) Nanobody detection of standard fluorescent proteins enables multi- target DNA-PAINT with high resolution and minimal displacement errors. Cells 8(1): 48.

Stanfield R.L., Wilson, I.A. (2014) Antibody structure. Microbiol. Spectrum 2(2). http://doi.org/10.1128/microbiolspec. AID-0012-2013

Strohl W.R. (2018) Current progress in innovative engineered antibodies. Protein Cell. 9(1): 86-120.

Svecova D., Lubell M.W., Casset-Semanaz F., Mackenzie H., Grenningloh R., Krueger J. (2019) A randomized, doubleblind, placebo-controlled phase 1 study of multiple ascending doses of subcutaneous M1095, an anti-interleukin $17 A / F$ nanobody, in moderate-to-severe psoriasis. J. Amer. Acad. Dermatol. 81(1): 196-203.

Talelli M., Oliveira S., Rijcken C., Pieters E., Etrych T., Ulbrich K., van Nostrum R.C., Storm G., Hennink W., Lammers T. (2013) Intrinsically active nanobody-modified polymeric micelles for tumor-targeted combination therapy. Biomaterials 34(4): 1255-1260.

Tanaka T., Narazaki M., Kishimoto T. (2014) IL- 6 in inflammation, immunity, and disease. Cold Spring Harbor Perspect. Biol. 6(10): a016295.

Tanha J., Xu P., Chen Z., Ni F., Kaplan H., Narang S. A., MacKenzie C. (2001) Optimal design features of camelized human single-domain antibody libraries. J. Biol. Chem. 276(27): 24774-24780.

Traenkle B., Rothbauer U. (2017) Under the microscope: single-domain antibodies for live-cell imaging and superresolution microscopy. Front. Immunol. 8: 1030.

Ubah O., Steven J., Kovaleva M., Ferguson L., Barelle C., Porter A., Barelle C. (2017) Novel, anti-hTNF- $\alpha$ variable new antigen receptor formats with enhanced neutralizing potency and multifunctionality, generated for therapeutic development. Front. Immunol. 8: 1780.

Van Roy M., Ververken C., Beirnaert E., Hoefman S., Kolkman J., Vierboom M., Breedveld E., 't Hart B., Poelmans S., Bontinck L., et al. (2015) The preclinical pharmacology of the high affinity anti-IL-6R Nanobody $\mathbb{R}$ ALX-0061 supports its clinical development in rheumatoid arthritis. Arthr. Res. Therapy 17(1): 135.

Vanlandschoot P., Stortelers C., Beirnaert E., Ibañez L.I., Schepens B., Depla E., Saelens X. (2011) Nanobodies ${ }^{\circledR}$ : new ammunition to battle viruses. Antiviral Res. 92(3): 389-407.

Vidarsson G., Dekkers G., Rispens T. (2014) IgG subclasses and allotypes: from structure to effector functions. Front. Immunol. 5: 520.

Vincke C., Loris R., Saerens D., Martinez-Rodriguez S., Muyldermans S., Conrath K. (2009) General strategy to humanize a camelid single-domain antibody and identification of a universal humanized nanobody scaffold. J. Biol. Chem. 284(5): 3273-3284.

Vincke C., Muyldermans S. (2012) Introduction to heavy chain antibodies and derived nanobodies. Meth. Mol. Biol. 911: $15-26$.

Vosjan M.J., Vercammen J., Kolkman J.A., Stigter-van Walsum M., Revets H., van Dongen G.A. (2012) Nanobodies tar- 
geting the hepatocyte growth factor: potential new drugs for molecular cancer therapy. Mol. Cancer Ther. 11(4): 1017-1025.

Wang Y., Fan Z., Shao L., Kong X., Hou X., Tian D., Sun Y., Xiao Y., Yu L. (2016) Nanobody-derived nanobiotechnology tool kits for diverse biomedical and biotechnology applications. Int. J. Nanomed. 11: 3287-3303.

Xu J., Mora A., Shim H., Stecenko A., Brigham K.L., Rojas M. (2007) Role of the SDF-1/CXCR4 axis in the pathogenesis of lung injury and fibrosis. Am. J. Respir. Cell Mol. Biol. 37: 291-299.

Yamaguchi Y., Kim H., Kato K., Masuda K., Shimada I., Arata Y. (1995) Proteolytic fragmentation with high specificity of mouse immunoglobulin $G$. mapping of proteolytic cleavage sites in the hinge region. J. Immun. Meth. 181(2): 259-267.

Yan J., Wang P., Zhu M., Li G., Romão E., Xiong S., Wan Y. (2015) Characterization and applications of nanobodies against human procalcitonin selected from a novel naïve nanobody phage display library. J. Nanobiotech. 13: 33.

Yang J., Liu D., Zhen S., Zhou Y., Zhang D., Yang L., Chen H., Feng Q. (2016) A novel anti-p21Ras scF $F_{\text {antibody reacting }}$ specifically with human tumour cell lines and primary tumour tissues. BMC cancer 16: 131.

Yau K., Groves M., Li S., Sheedy C., Lee H., Tanha J., MacKenzie C.R., Jermutus L., Hall J. (2003) Selection of hapten-specific single-domain antibodies from a non-immuni- zed llama ribosome display library. J. Immunol. Meth. 281(1-2): 161-175.

Zhang M., Dimitrov D (2007) Novel approaches for identification of broadly cross-reactive HIV-1 neutralizing human monoclonal antibodies and improvement of their potency. Curr. Pharmaceut. Design 13(2): 203-212.

Zielonka S., Empting M., Grzeschik J., Könning D., Barelle C.J., Kolmar H. (2015) Structural insights and biomedical potential of IgNAR scaffolds from sharks. MAbs 7(1): 15-25.

Zolghadr K., Gregor J., Leonhardt H., Rothbauer U. (2012) Case study on live cell apoptosis-assay using lamin-chromobody cell-lines for high-content analysis. Meth. Mol. Biol. 911: 569-575.

Zou X., Osborn M., Bolland D., Smith J., Corcos D., Hamon M., Oxley D., Hutchings A., Morgan G., Santos F., et al. (2007) Heavy chain-only antibodies are spontaneously produced in light chain-deficient mice. J. Exp. Med. 204(13): 3271-3283.

Zou X., Smith J., Nguyen V., Ren L., Luyten K., Muyldermans S., Brüggemann M. (2005) Expression of a dromedary heavy chain-only antibody and $B$ cell development in the mouse. J. Immunol. 175(6): 3769-3779. 